\title{
Distribution and contamination assessment of heavy metals in soils and sediments from the Fildes Peninsula and Ardley Island in King George Island, Antarctica
}

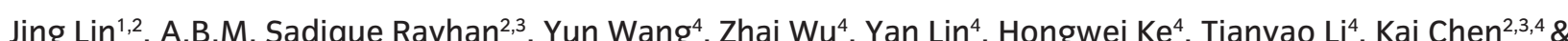
Minggang Cai ${ }^{2,3,4}$

\author{
${ }^{1}$ Laboratory of Marine Isotopic Technology and Environmental Risk Assessment, Third Institute of Oceanography, Ministry of Natural Resources, \\ Xiamen, China \\ ${ }^{2}$ Fujian Provincial Key Laboratory for Coastal Ecology and Environmental Studies, Xiamen University, Xiamen, China \\ ${ }^{3}$ Coastal and Ocean Management Institute, Xiamen University, Xiamen, China \\ ${ }^{4}$ College of Ocean and Earth Science, Xiamen University, Xiamen, China
}

\begin{abstract}
Concentrations of heavy metals $(\mathrm{Cu}, \mathrm{Pb}, \mathrm{Zn}, \mathrm{Cd}$ and $\mathrm{Cr})$ in surface soils and sediments collected in 2008 from 37 sampling sites in the Fildes Peninsula and Ardley Island were detected by atomic absorption spectrometry. The total contents of $\mathrm{Cu}, \mathrm{Pb}, \mathrm{Zn}, \mathrm{Cd}$ and $\mathrm{Cr}$ ranged, respectively, from 61.36 to $562.2 \mathrm{mg} / \mathrm{kg}$, 0.52 to $1.95 \mathrm{mg} / \mathrm{kg}, 54.61$ to $577.9 \mathrm{mg} / \mathrm{kg}, 0.04$ to $3.76 \mathrm{mg} / \mathrm{kg}$ and 6.83 to 25.9 $\mathrm{mg} / \mathrm{kg}$ in soils and from 58.55 to $498.3 \mathrm{mg} / \mathrm{kg}, 0.60$ to $2.51 \mathrm{mg} / \mathrm{kg}, 56.22$ to $345.9 \mathrm{mg} / \mathrm{kg}, 0.07$ to $5.77 \mathrm{mg} / \mathrm{kg}$ and 7.76 to $39.5 \mathrm{mg} / \mathrm{kg}$ in sediments. The geo-accumulation index and the pollution load index were calculated to evaluate the environmental effects of heavy metal pollutants, $\mathrm{Cu}, \mathrm{Zn}$ and $\mathrm{Cd}$, in the study area. Soils and sediments from Ardley Island were found to be moderately polluted with the studied metals. Pearson's correlation analysis and principal component analysis were applied to assess the distribution pattern and potential source of heavy metals. The results suggest that $\mathrm{Cu}, \mathrm{Zn}$ and $\mathrm{Cd}$ in the study area originated from both the lithogenic sources and penguin guano, while $\mathrm{Pb}$ and $\mathrm{Cr}$ were probably derived from lithogenic sources.
\end{abstract}

\section{Keywords}

Trace element content; pollution assessment; penguin guano; multivariate statistical analysis; bio-transport of metals

\section{Correspondence}

Kai Chen, 4221 Xiangan South Road, Xiamen 361102, China. E-mail: kchen@xmu.edu.cn

\section{Abbreviations}

ASPA: Antarctic Specially Protected Area PLI: pollution load index

\section{Introduction}

The persistence, potential toxicity and bioaccumulation of heavy metals make them the most important contaminants in the environment (Kaushik et al. 2009; Yang et al. 2009). Heavy metals can be adsorbed to the particulate matter in aquatic systems and will finally accumulate in sediments (Wang et al. 2015; Chen et al. 2018). However, the remobilization of heavy metals from surface sediments can cause contamination of the surrounding waters (Yuan et al. 2004). Sediments, therefore, play an important role as both sinks and potential secondary sources of heavy metals in aquatic ecosystems, and it is particularly important to explore the heavy metal contents in the surface sediments (Zhang et al. 2016).

Considered as the last great wilderness, Antarctica is the most isolated and remote continent on this planet. However, this does not protect Antarctica from the deleterious impacts of pollution. Contaminants from lower latitudes can reach the polar regions through atmospheric transport, current transport and even animal activities (Majer et al. 2014; Chu et al. 2019). Increasing human activities in Antarctica have caused several environmental pollution problems after the International Geophysical Year (1957-58), mainly near scientific stations (Santos et al. 2005). King George Island, the largest island in the South Shetlands Islands, has a high density of scientific stations, especially on the Fildes Peninsula, where six scientific stations have been established between 1968 and 1994 (Amaro et al. 2015; Bueno et al. 2018). In addition, the recent increase in the number of tourists to Antarctica has caused widespread environmental concerns (Kariminia et al. 2013).

A number of studies have investigated heavy metal pollution in several environmental matrices in Antarctica (e.g., Wolff et al. 1999; Sheppard et al. 2000; Planchon et al. 2002; Webster et al. 2003; Santos et al. 2005; Santos et al. 2006; Chaparro et al. 2007; Huang et al. 2014; Trevizani et al. 2016). Heavy metal concentrations in soils and lake sediments have been reported from the Fildes Peninsula and 
Ardley Island, a small island close off King George Island (Lu et al. 2012; Amaro et al. 2015; Bueno et al. 2018). These studies particularly focused on heavy metals near the scientific stations. Surveys carried out in different years will improve our understanding of the cumulative environmental and anthropogenic changes occurring there.

This study reported here aimed to determine and evaluate the levels of $\mathrm{Cu}, \mathrm{Pb}, \mathrm{Zn}, \mathrm{Cd}$ and $\mathrm{Cr}$ in samples of soils and coastal sediments collected in 2008 from the Fildes Peninsula and Ardley Island, and to consider their possible sources. Nearly all of the areas that are affected by bird and human activities on the Fildes Peninsula and Ardley Island were sampled in this study.

\section{Materials and methods}

\section{Study sites}

The Fildes Peninsula, in south-western King George Island, is the second-largest ice-free coastal area $\left(29 \mathrm{~km}^{2}\right)$ during summer in the South Shetland Islands of Antarctica. The climate here is cold, moist and maritime, with a mean annual air temperature of $-2.2^{\circ} \mathrm{C}$ and about $630 \mathrm{~mm}$ in annual precipitation (Michel et al. 2014). The soil from the Fildes Peninsula consists mostly of weathered volcanic rocks, especially andesitic basalts (Li et al. 1992). ASPA No. 125 was designated to protect two geologically important sites on the peninsula (Peter et al. 2008).

Ardley Island $\left(62^{\circ} 12^{\prime} 0^{\prime \prime} \mathrm{S}, 58^{\circ} 54^{\prime} 0^{\prime \prime} \mathrm{W}\right)$ is $2 \mathrm{~km}$ in length and $1.5 \mathrm{~km}$ in width, and is connected to the Fildes Peninsula by a 400-m long isthmus, exposed during low tides (Michel et al. 2014). Ardley Island hosts one of the largest breeding gentoo penguin (Pygoscelis papua) colonies in the Antarctic, alongside Adélie ( $P$. adeliae) and chinstrap ( $P$. antarcticus) penguins (Roberts et al. 2017). Because of its diverse community of birds and terrestrial plants, Ardley Island has been designated ASPA No. 150 for intensive research studies; however, it also includes a visitor zone (Peter et al. 2008).

\section{Sampling strategy}

A total of 37 sampling sites (Fig. 1) were selected in the study areas during the 25th Scientific Antarctic Expedition of China in December 2008. Twenty-six soil samples were collected from the Fildes Peninsula (A-2-A-4, T-1-T-3, T-5T-13 and S-2-S-9) and Ardley Island (A-5-A-7). Eleven coastal sediment samples were collected from Maxwell Bay (A-1) and the Great Wall Bay (S-1, S-10-S-14, A-8-A-11).

Soil samples (top $10 \mathrm{~cm}$ ) were taken with a plastic spatula, while surface sediment samples (top $2 \mathrm{~cm}$ ) were taken from the Van Veen grab sampler with a plastic scoop. The collected samples were stored in acid-washed polyethylene bags, and then transported to the laboratory and frozen at $-18^{\circ} \mathrm{C}$ before further analysis.

\section{Sample analysis}

After freeze-drying for at least 24 hours, sediment samples were divided into two sub-samples, one for the grain size study and the other for the heavy metal analysis.

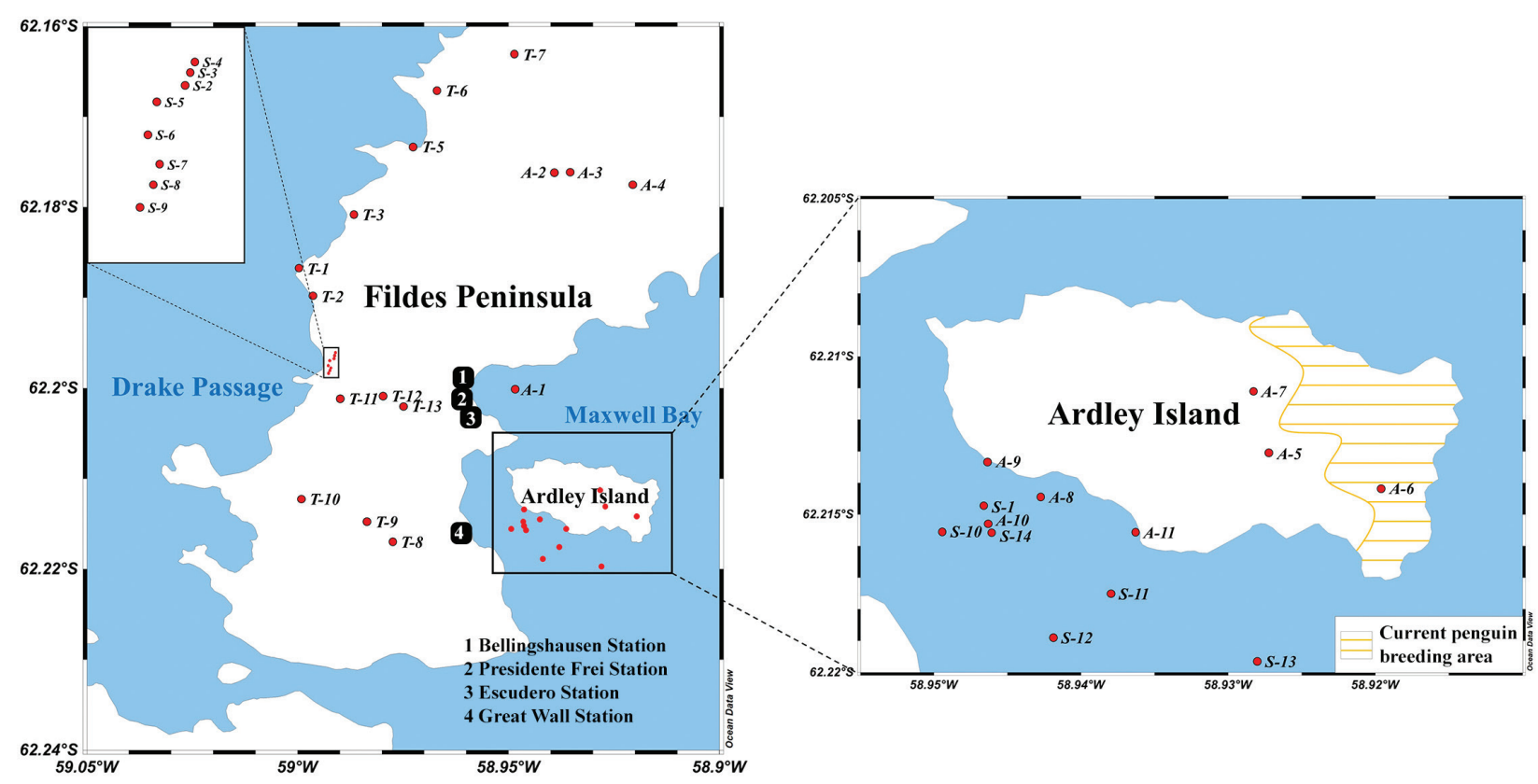

Fig. 1 Map of sampling sites in the Fildes Peninsula and Ardley Island. The extent of the penguin breeding area is taken from Roberts et al. (2017). 
Table 1 Measured and certified values of metal contents in standard reference material.

\begin{tabular}{lcccc}
\hline Element & $\begin{array}{c}\text { Limit of detection } \\
(\mu \mathrm{g} / \mathrm{L})\end{array}$ & $\begin{array}{c}\text { Measured value } \\
(\mu \mathrm{g} / \mathrm{g})\end{array}$ & $\begin{array}{c}\text { Assigned value } \\
(\mu \mathrm{g} / \mathrm{g})\end{array}$ & $\begin{array}{c}\mathrm{RSD}^{\mathrm{a}} \\
(\%)\end{array}$ \\
\hline $\mathrm{Cu}$ & 0.10 & $36.15 \pm 1.15$ & $32 \pm 2$ & 3.17 \\
$\mathrm{~Pb}$ & 0.19 & $59.06 \pm 2.10$ & $61 \pm 2$ & 3.56 \\
$\mathrm{Zn}$ & 1.58 & $116.12 \pm 1.31$ & $100 \pm 8$ & 1.13 \\
$\mathrm{Cd}$ & 0.02 & $0.23 \pm 0.01$ & $0.25 \pm 0.02$ & 2.47 \\
$\mathrm{Cr}$ & 0.62 & $67.70 \pm 3.57$ & $67 \pm 3$ & 5.28 \\
\hline
\end{tabular}

a Relative standard deviation.

Particle-size distribution was determined by a Laser Mastersizer 2000. Other sub-samples were powdered and homogenized with an agate mortar to pass through a 180-mesh sieve $(80 \mu \mathrm{m})$ for metal analysis. For each of the powdered samples, $0.1 \mathrm{~g}$ was digested with a mixture of $\mathrm{HNO}_{3}$ and $\mathrm{HClO}_{4}$, using the method described by Cai et al. (2011). Samples were then analysed by flame atomic absorption spectrometry for $\mathrm{Zn}$ and by graphite furnace atomic absorption spectrometry for $\mathrm{Cu}, \mathrm{Cd}, \mathrm{Pb}$ and $\mathrm{Cr}$ (SOLAAR M6, Thermo Scientific Co.).

Milli-Q water was used throughout the study. All glassware, plasticware, pipette tips and polytetrafluoroethylene vessels were soaked in $\mathrm{HNO}_{3}$ solution $(1: 3 \mathrm{v} / \mathrm{v})$ for at least 48 hours and rinsed with Milli-Q water before use. Quality assurance and quality control were assessed using method blanks, duplicate samples and standard reference material (GBW07314) in triplicate. The results for the selected metals are shown in Table 1 . The recoveries obtained in the standard reference material ranged from 92 to $116 \%$. The relative standard deviation (\%), indicating the precision of duplicate samples, ranged from 1.13 to $5.28 \%$.

\section{Assessment of sediment contamination}

Geo-accumulation index $\left(\boldsymbol{I}_{\text {geo }}\right)$. The widely applied geo-accumulation index $\left(I_{\text {geo }}\right)$ is used to evaluate the heavy metal contamination status of sediments in a water body (Müller 1969). It is calculated by the following equation:

$$
I_{\text {geo }}=\log _{2}\left(C_{n} / 1.5 \times B_{n}\right),
$$

where $C_{n}$ is the measured metal concentration $(n), B_{n}$ is the concentration of metal in the geochemical background $(n)$, and 1.5 is the background matrix correlation factor of the lithogenic and anthropogenic influences (Hakanson 1980; Sheppard et al. 2000). The geo-accumulation index can be divided into seven classes from class 0 to class 6: $I_{\text {geo }}$ values of $\leq 0$ suggest unpolluted, $0<I_{\text {geo }} \leq 1$ indicates unpolluted to moderately polluted, 1 $<I_{g e o} \leq 2$ suggests moderately polluted, $I_{\text {geo }}$ values of 2-3 represent moderately to heavily polluted, $3<I_{\text {geo }} \leq 4$ suggests heavily polluted, $4<I_{\text {geo }} \leq 5$ demonstrates heavily to extremely polluted and values exceeding 5 indicate severely polluted (Müller 1979).

PLI. PLI provides a simple and reliable way to assess the polymetallic contamination of sediment (Tomlinson et al. 1980), which is calculated by the following equation:

$$
\mathrm{PLI}=\left(C F_{1} \times C F_{2} \times C F_{3} \times \cdots \times C F_{n}\right)^{1 / n},
$$

where CF is the contamination factor and $\mathrm{n}$ is the number of analysed metals. CF is the ratio obtained by dividing the content of each metal in sediment by the background value that was developed by Hakanson (1980). According to Tomlinson et al. (1980), PLI > 1 indicates the presence of polymetallic pollution, while there is no metal pollution when PLI $<1$.

In this study, the background values of heavy metals on the Fildes Peninsula are adopted from Lu et al. (2012), which was determined by the method of relative cumulative frequency. The background concentrations of $\mathrm{Cu}, \mathrm{Pb}$, $\mathrm{Zn}, \mathrm{Cd}$ and $\mathrm{Cr}$ were 89.45, 5.44, 51.41, 0.09 and $22.56 \mathrm{mg} / \mathrm{kg}$, respectively.

\section{Multivariate statistical analyses}

We applied Pearson's correlation analysis to determine the relationships among all the selected heavy metals and particle-size distribution. A two-tailed $p$ value of $<0.05$ was considered to be statistically significant. Principal component analysis was used to discriminate the potential sources of heavy metals based on the similarities of their chemical properties. Principal component analysis was applied with Kaiser-Meyer-Olkin and Bartlett's sphericity tests and was performed on the correlation matrix of normalized variables. To extract significant principal components and to further reduce the contribution of variables with minor significance, principal components were subjected to varimax rotation.

All statistical analyses were performed with IBM $^{\circledR}$ SPSS $^{\circledR} 25.0$ software for Windows and Origin 2021.

\section{Results and discussion}

\section{Particle-size analysis}

Coarse sand $(>250 \mu \mathrm{m})$, fine sand $(63-250 \mu \mathrm{m})$, silt (4-63 $\mu \mathrm{m})$ and clay $(<4 \mu \mathrm{m})$ fractions in soils and sediments of the Fildes Peninsula and Ardley Island ranged from 0 to $44.9 \%$, 14.5 to $58.3 \%, 14.5$ to $72.2 \%$ and 0.39 to $18.1 \%$, respectively (Table 2). Particle-size distributions varied greatly among the studied sites, with silt and fine sand being the predominant fractions in soils and sediments (Fig. 2). The 
Table 2 Particle-size fraction (\%) and heavy metal concentrations $(\mathrm{mg} / \mathrm{kg})$ in this study.

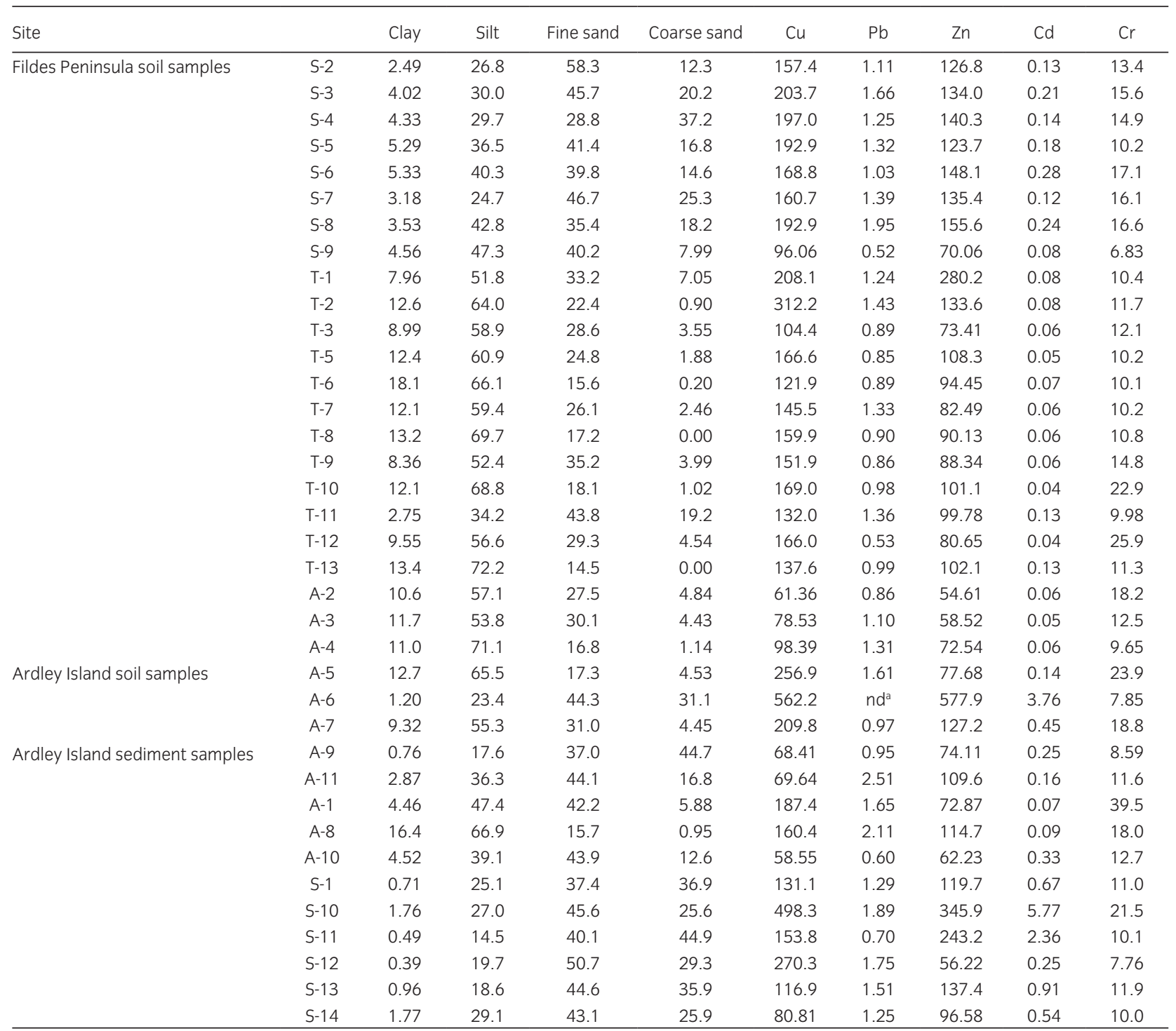

${ }^{a}$ No data.

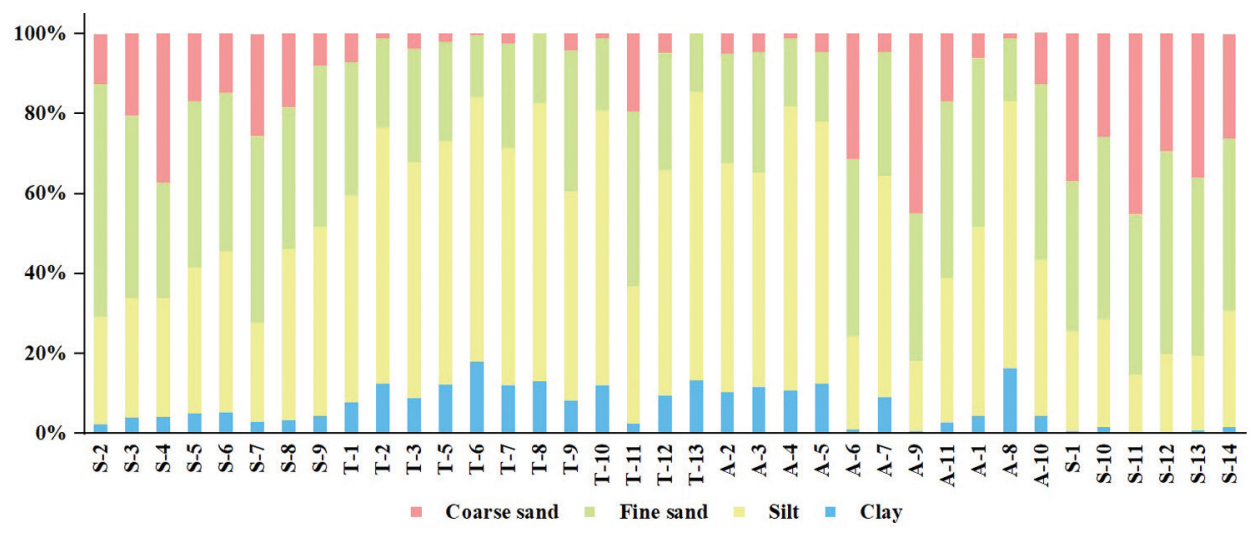

Fig. 2 The particle-size distributions of sampling sites in the Fildes Peninsula and Ardley Island. 
Table 3 Comparison of heavy metal concentrations in sediments and soils from different areas in the Antarctic (mean \pm SD, mg/kg).

\begin{tabular}{|c|c|c|c|c|c|c|}
\hline & Location & $\mathrm{Cu}$ & $\mathrm{Pb}$ & $\mathrm{Zn}$ & $\mathrm{Cd}$ & $\mathrm{Cr}$ \\
\hline \multirow[t]{6}{*}{ Soil } & Fildes Peninsula $^{a}$ & $155.8 \pm 52.7$ & $1.12 \pm 0.34$ & $111.1 \pm 47.0$ & $0.10 \pm 0.07$ & $13.5 \pm 4.5$ \\
\hline & Ardley Island ${ }^{a}$ & $343.0 \pm 191.3$ & $1.29 \pm 0.45$ & $260.9 \pm 275.6$ & $1.45 \pm 2.01$ & $16.8 \pm 8.2$ \\
\hline & Ardley Island ${ }^{b}$ & $30 \pm 6$ & $23 \pm 3$ & $104 \pm 7$ & $0.28 \pm 0.04$ & \\
\hline & Fildes Peninsula ${ }^{c}$ & $122.30 \pm 32.12$ & $15.87 \pm 13.49$ & $58.69 \pm 9.36$ & $0.17 \pm 0.08$ & $31.95 \pm 13.82$ \\
\hline & Fildes Peninsula: human-affected soils ${ }^{d}$ & $186.33 \pm 36.00$ & $203.16 \pm 49.91$ & $134.67 \pm 26.50$ & $0.44 \pm 0.22$ & \\
\hline & Marambio Station, Seymour Islande & 6.1 & 10.2 & 36 & $<0.8$ & 22 \\
\hline \multirow[t]{3}{*}{ Sediment } & Maxwell Bay and Great Wall Baya & $163.2 \pm 127.7$ & $1.47 \pm 0.59$ & $130.2 \pm 88.2$ & $1.04 \pm 1.70$ & $14.8 \pm 9.1$ \\
\hline & Collins Harbor ${ }^{f}$ & 77 & 8.7 & 69 & 0.22 & 7.6 \\
\hline & Ferraz Stations & 67 & 5.5 & 52 & & 35 \\
\hline Rocks & Global average ${ }^{h}$ & 25 & 14.8 & 65 & 0.10 & 126 \\
\hline
\end{tabular}

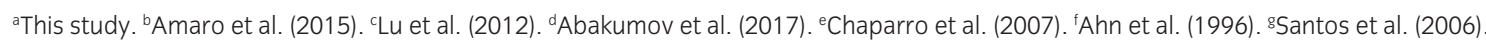

hWedepohl (1995).

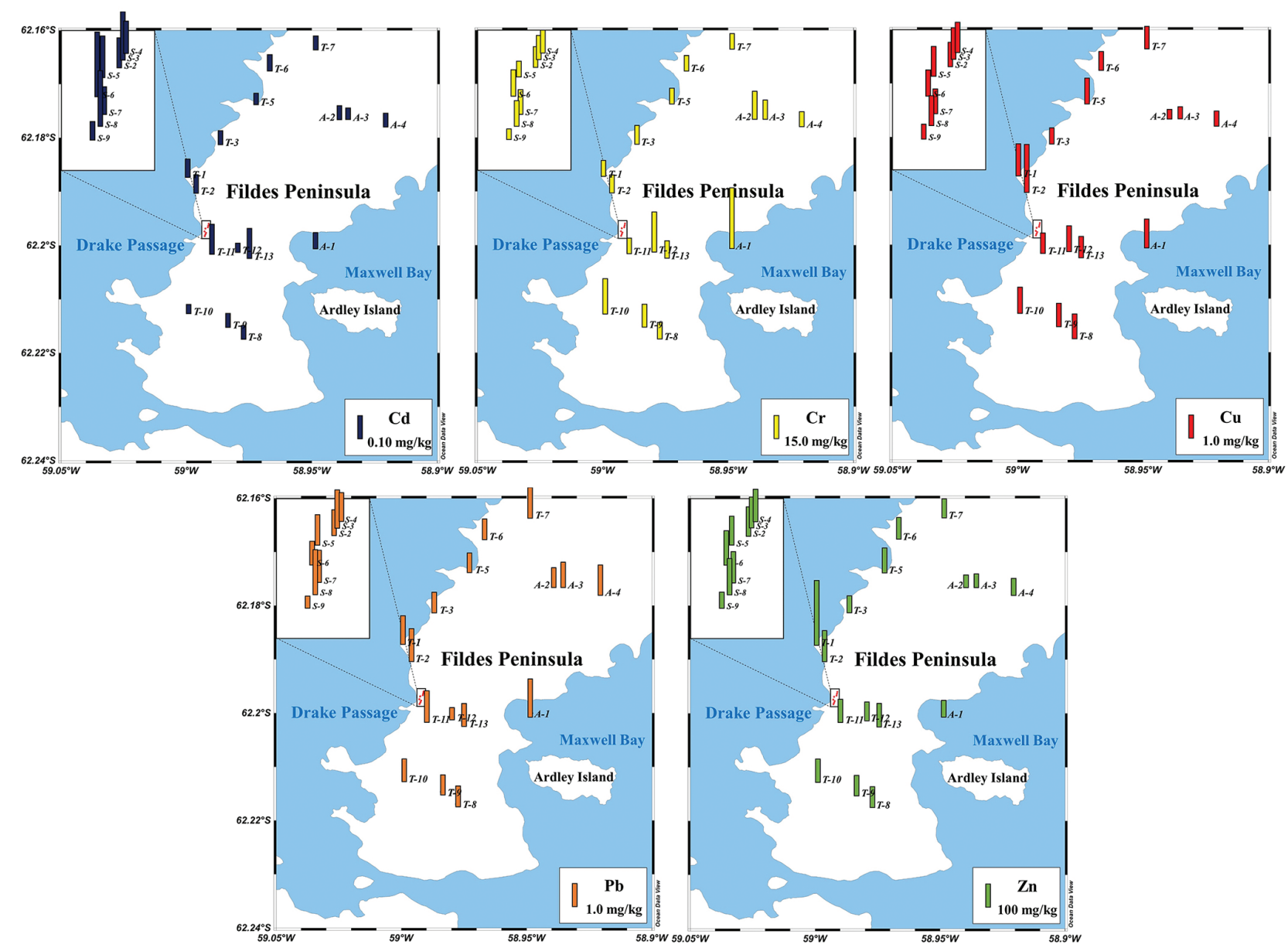

Fig. 3 The distribution of heavy metals in soils on the Fildes Peninsula. 
Table 4 Geo-accumulation indexes and PLI in soils and sediments from the Fildes Peninsula and Ardley Island.

\begin{tabular}{|c|c|c|c|c|c|c|c|}
\hline \multirow[t]{2}{*}{ Sample type (number of samples) } & & \multicolumn{5}{|c|}{$l_{\text {geo }}$} & \multirow[t]{2}{*}{ PLI } \\
\hline & & $\mathrm{Cu}$ & $\mathrm{Pb}$ & $\mathrm{Zn}$ & $\mathrm{Cd}$ & $\mathrm{Cr}$ & \\
\hline & $S D^{a}$ & 0.51 & 0.46 & 0.53 & 0.83 & 0.44 & 0.23 \\
\hline \multirow[t]{2}{*}{ Soil, Ardley Island $(n=3)$} & mean & 1.22 & -2.71 & 1.21 & 2.20 & -1.15 & 1.25 \\
\hline & $\mathrm{SD}^{\mathrm{a}}$ & 0.75 & 0.52 & 1.51 & 2.41 & 0.85 & 0.13 \\
\hline \multirow[t]{2}{*}{ Sediment $(n=11)$} & mean & -0.02 & -2.59 & 0.53 & 1.67 & -1.37 & 1.32 \\
\hline & $\mathrm{SD}^{\mathrm{a}}$ & 0.94 & 0.65 & 0.81 & 1.93 & 0.68 & 0.87 \\
\hline
\end{tabular}

astandard deviation.

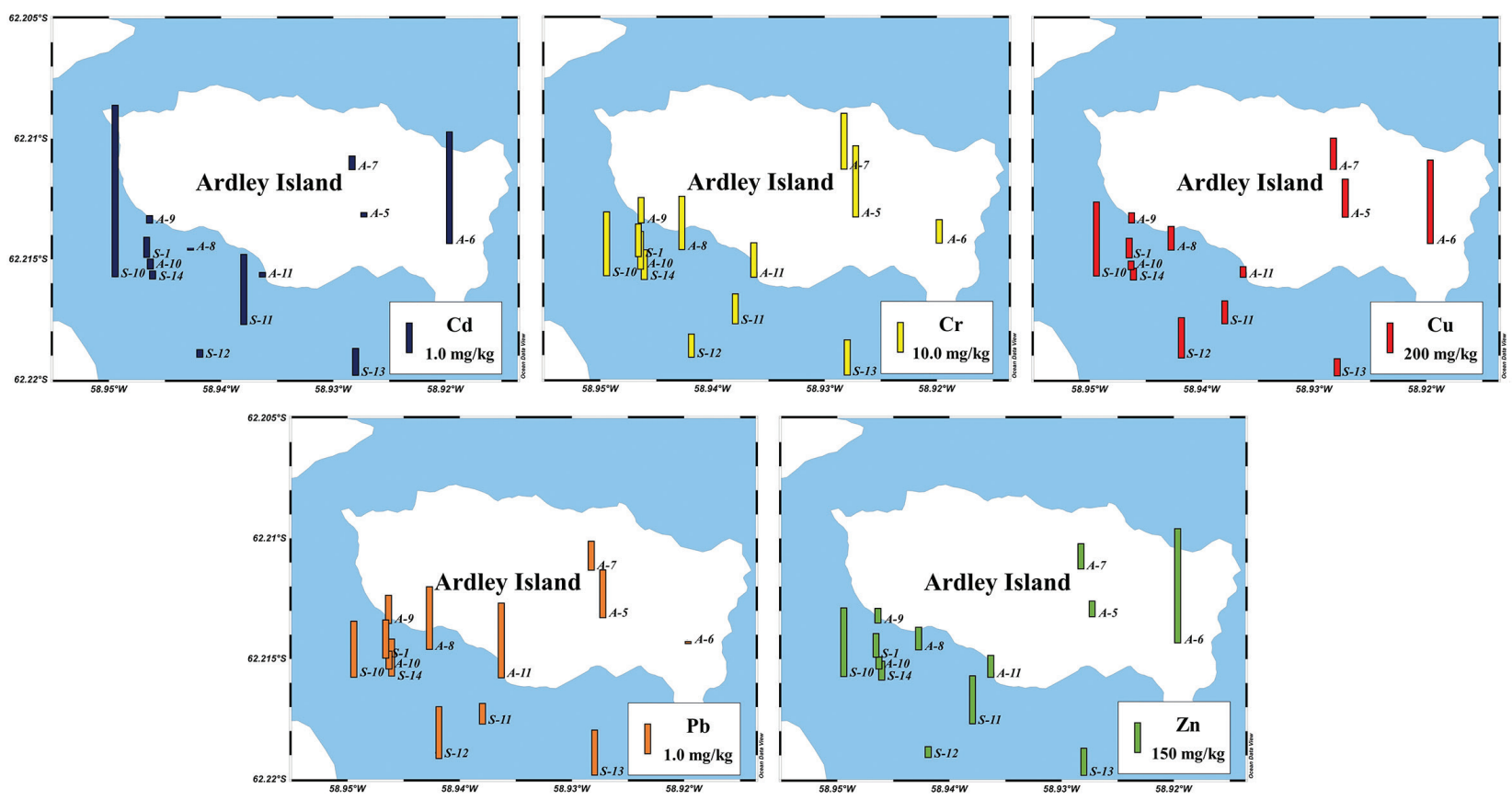

Fig. 4 The distribution of metals in soils and sediments on Ardley Island.

clay fractions of surface soils and sediments were relatively low in the study area, which is consistent with a study by Michel et al. (2014) that reported low clay content in soils from the Fildes Peninsula and Ardley Island.

\section{Concentrations of heavy metals}

The concentrations of heavy metals from different areas of the Fildes Peninsula and Ardley Island are shown in Table 2. The concentrations of $\mathrm{Cu}, \mathrm{Pb}, \mathrm{Zn}, \mathrm{Cd}$ and $\mathrm{Cr}$ in soils and sediments were in the range of 58.55-562.2 mg/ $\mathrm{kg}$ (average $173.2 \pm 104.3 \mathrm{mg} / \mathrm{kg}$ ), 0.52-2.51 mg/kg (average $1.24 \pm 0.45 \mathrm{mg} / \mathrm{kg}$ ), $54.61-577.9 \mathrm{mg} / \mathrm{kg}$ (average $128.9 \pm 96.9 \mathrm{mg} / \mathrm{kg}$ ), $0.04-5.77 \mathrm{mg} / \mathrm{kg}$ (average
$0.49 \pm 1.14 \mathrm{mg} / \mathrm{kg}$ ) and $6.83-39.5 \mathrm{mg} / \mathrm{kg}$ (average $14.2 \pm$ $6.3 \mathrm{mg} / \mathrm{kg}$ ), respectively.

Compared with the Earth's crust values (Wedepohl 1995), the concentrations of $\mathrm{Cu}, \mathrm{Zn}$ and $\mathrm{Cd}$ in the Fildes Peninsula and Ardley Island found in this study were significantly higher, except for Cd in Fildes Peninsula soils (Table 3). The concentrations of $\mathrm{Cu}, \mathrm{Zn}$ and $\mathrm{Cd}$ in soils from the Fildes Peninsula found in this study were lower than those in human-affected soils (Abakumov et al. 2017). Compared to pristine areas in the Antarctic (Ahn et al. 1996; Santos et al. 2006; Chaparro et al. 2007; Lu et al. 2012; Amaro et al. 2015; Abakumov et al. 2017), the concentrations of $\mathrm{Cu}, \mathrm{Zn}$ and $\mathrm{Cd}$ in soils and sediments from the Fildes Peninsula and Ardley Island were 


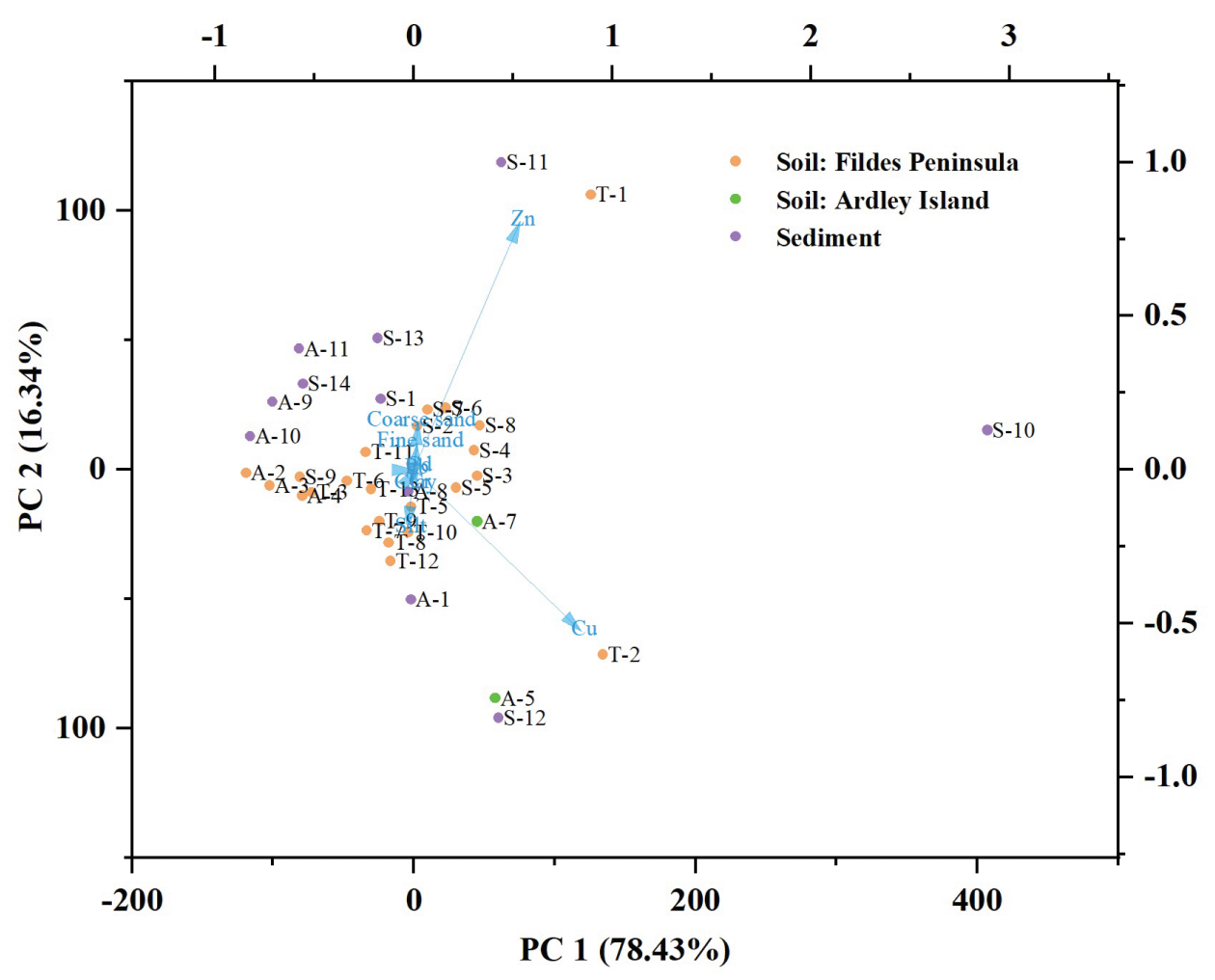

Fig. 5 Principal component analysis biplot of heavy metal concentrations $(\mathrm{mg} / \mathrm{kg})$ and particle-size fraction (\%) at the sampling sites on the Fildes Peninsula and Ardley Island.

higher, with the exception of Cd levels in Fildes Peninsula soils. In other words, our sampling sites on the Fildes Peninsula were affected by $\mathrm{Zn}$ and $\mathrm{Cu}$ (Ribeiro et al. 2011; Trevizani et al. 2016), and the Ardley Island sediments were affected by $\mathrm{Zn}, \mathrm{Cu}$ and $\mathrm{Cd}$.

The relatively high concentrations of $\mathrm{Zn}$ and $\mathrm{Cu}$ could be associated with a mineralogical origin where basaltandesite rocks predominate (Bueno et al. 2018). Another reasonable explanation is that penguins transport heavy metals in Antarctic coastal areas (Santamans et al. 2017). Over 10000 penguins live on Ardley Island during the breeding season, producing about 139 tonnes of faeces rich in heavy metals (Wang et al. 2007; Roberts et al. 2017; Fig. 1). Celis et al. (2015) found that gentoo penguins transfer bio-accumulated metals into terrestrial ecosystems via excreta. In this study, higher concentrations of $\mathrm{Zn}, \mathrm{Cu}$ and $\mathrm{Cd}$ were found at site A-6, located in the penguin nesting area, whereas lower levels were observed at sites A-5 and A-7, which were beyond the penguin nesting area (Fig. 4). This suggests that penguins transfer a large quantity of heavy elements from the ocean to the island. There were no significant differences in $\mathrm{Cr}$ and $\mathrm{Pb}$ values among the sampling sites on the Fildes Peninsula and Ardley Island (Figs. 3, 4). As the distribution patterns of $\mathrm{Cr}$ and $\mathrm{Pb}$ were uniform and much lower than those in pristine areas (Lu et al. 2012; Abakumov et al. 2017), they are considered not to be affected by human influences and could be related to lithogenic inputs in this study area (Azhari et al. 2016).

\section{Pollution assessment}

Geo-accumulation index. $I_{g e o}$ values of heavy metals in soils and sediments from the Fildes Peninsula and Ardley Island are presented in Table 4. The $I_{\text {geo }}$ values of $\mathrm{Cu}$ and $\mathrm{Zn}$ in soils from the Fildes Peninsula were lower than 1.0, indicating that this area was "unpolluted to moderately polluted" by these two metals. The soils from Ardley Island were found to be "moderately polluted," with $\mathrm{Cu}$ and $\mathrm{Zn}\left(1<I_{\text {geo }} \leq 2\right)$, and "moderately to heavily polluted," with Cd $(2.20 \pm 2.41)$. I $I_{\text {geo }}$ values of metals in sediments suggested that the study area was "unpolluted to moderately polluted" by Zn and "moderately polluted" by $\mathrm{Cd}$. In contrast, the average geo-accumulation indexes of $\mathrm{Pb}$ and $\mathrm{Cr}$ were both less than zero, indicating an unpolluted level.

PLI. Soils from the Fildes Peninsula were calculated with a mean PLI of 0.85 , which means no pollution (Table 4 ). 
Table 5 The results of Pearson's correlation analysis between heavy metals and particle size. Boldface indicates statistical significance at the < 0.05 level (two-tailed); italics indicate significance at the $<0.01$ level (two-tailed).

\begin{tabular}{|c|c|c|c|c|c|c|c|c|c|}
\hline Metal & $\mathrm{Cu}$ & $\mathrm{Pb}$ & $\mathrm{Zn}$ & $\mathrm{Cd}$ & $\mathrm{Cr}$ & Clay & Silt & Fine sand & Coarse sand \\
\hline$\overline{\mathrm{Cu}}$ & 1 & & & & & & & & \\
\hline $\mathrm{Pb}$ & 0.361 & 1 & & & & & & & \\
\hline $\mathrm{Zn}$ & 0.798 & 0.235 & 1 & & & & & & \\
\hline $\mathrm{Cd}$ & 0.730 & 0.181 & 0.784 & 1 & & & & & \\
\hline $\mathrm{Cr}$ & 0.132 & 0.171 & -0.114 & 0.011 & 1 & & & & \\
\hline Silt & -0.201 & -0.188 & -0.367 & -0.423 & 0.191 & 0.934 & 1 & & \\
\hline Fine sand & 0.170 & 0.181 & 0.269 & 0.310 & -0.060 & -0.884 & -0.860 & 1 & \\
\hline Coarse sand & 0.185 & 0.161 & 0.374 & 0.434 & -0.240 & -0.840 & -0.921 & 0.603 & 1 \\
\hline
\end{tabular}

In contrast, the mean PLIs of soils and coastal sediments from Ardley Island were both more than 1, suggesting that the area was moderately polluted by metals.

\section{Multivariate statistical analyses}

Pearson's correlation analysis. Heavy metals in soils showed no significant correlation with the particle-size distribution (Table 5). This was unexpected as heavy metals have generally been found to be associated with the fine-grain fraction in sediments (Chen et al. 2016). The same result was also observed near Artigas Base and Ferraz Station (Santos et al. 2005; Bueno et al. 2018), also located on King George Island, indicating that heavy metal concentrations in soils and sediments cannot be interpreted simply by a change in grain size.

Significant positive correlations were observed among $\mathrm{Cu}, \mathrm{Zn}$ and $\mathrm{Cd}$, while $\mathrm{Pb}$ and $\mathrm{Cr}$ were not significantly correlated with any other metals (Table 5). The results suggested a similar biogeochemical behaviour for $\mathrm{Cu}, \mathrm{Zn}$ and Cd. Santamans et al. (2017) demonstrated that greater penguin activity was associated with higher levels of certain pollutants in soils, especially $\mathrm{Cd}, \mathrm{Cu}, \mathrm{As}, \mathrm{Zn}$ and Se.

Principal component analysis. The Kaiser-MeyerOlkin value was 0.695, and the significance of Bartlett's sphericity test was less than 0.01 , which indicated that principal component analysis for this study was significant. All sites could be grouped into two principal components, PC1 and PC2, which account for $94.77 \%$ of the total variance (Fig. 5). PC1 and PC2 generated 78.43\% and $16.34 \%$ of the variance, respectively. A positive (negative) score indicates that the influence of variables increases (decreases) along a principal component axis, and a score near 0 indicates that the influence of variables is poorly related to the principal component axis (Wang et al. 2021). We observed obtuse angles (i.e., negative correlation) between the $\mathrm{Cu}$ and $\mathrm{Zn}$; however, $\mathrm{Cu}$ was significantly correlated with Zn based on Pearson's correlation test $(R=0.798, p<0.05$; Fig. 5, Table 5). This may be an artefact of the principal component analysis used in this study, which was based on a covariance matrix, because the units of heavy metal concentration and particle size are different (Singh et al. 2005).

The distributions of other variables- $\mathrm{Pb}, \mathrm{Cd}, \mathrm{Cr}$, clay, silt, fine sand and coarse sand-were hardly affected by either $\mathrm{PC} 1$ or PC2, as they are close to the origin of coordinates. The locations (e.g., Tl and S11) on the positive side end of the $\mathrm{Zn}$ axis had concentrations of $\mathrm{Zn}$ higher than that of $\mathrm{Cu}$ in soils or sediments. In contrast, the locations (e.g., A5, S12 and $\mathrm{T} 2$ ) on the positive side end of the $\mathrm{Cu}$ axis had concentrations of $\mathrm{Cu}$ higher than that of $\mathrm{Zn}$ in soils or sediments. Considering their geographical proximity, especially $\mathrm{Tl}$ and $\mathrm{T} 2$, and S11 and S12, it seems that this difference did not originate from external factors, such as air deposition or penguin activities. We speculate that local human activities or geological features are possible sources leading to the differences found (Boutron \& Wolff 1989; Lu et al. 2012); however, further study is needed to confirm this.

\section{Conclusion}

The results of this study provide an overview of selected heavy metals in samples of surface soils and coastal sediments collected in 2008 from the Fildes Peninsula and Ardley Island, Antarctica. Calculations of $I_{\text {geo }}$ for soils and sediments from the Fildes Peninsula and Ardley Island showed an accumulation of $\mathrm{Cu}, \mathrm{Zn}$ and $\mathrm{Cd}$. PLI results demonstrated that soils and sediments on Ardley Island were moderately polluted with these metals. These areas can be considered unpolluted by $\mathrm{Pb}$ and $\mathrm{Cr}$. The study strongly suggests that $\mathrm{Cu}, \mathrm{Zn}$ and $\mathrm{Cd}$ in the study area originate from the lithogenic sources and penguin guano, whereas $\mathrm{Pb}$ and $\mathrm{Cr}$ probably derive from lithogenic 
sources alone. Seabird activities have increased the amount of $\mathrm{Cu}, \mathrm{Zn}$ and $\mathrm{Pb}$ on Ardley Island. It is necessary to monitor the bio-transport of trace metals and their impact on the food chain of Antarctica.

When compared with other published heavy metal concentrations on the Fildes Peninsula and Ardley Island since our sampling, $\mathrm{Cu}, \mathrm{Zn}$ and $\mathrm{Cd}$ levels in soils became higher after 2008, especially near human-affected locations, such as research stations. In the pristine soils of the area, however, $\mathrm{Cu}$ and $\mathrm{Zn}$ remained constant.

\section{Acknowledgements}

The authors thank the crews of CHINARE-25 and the group members for their help in sampling and analysis. They also thank the anonymous reviewers for their patience and kind and valuable comments.

\section{Disclosure statement}

The authors report no conflict of interest.

\section{Funding}

This research work was supported by the National Natural Science Foundation of China (grant nos. 41776088, 41976216), the National Social Science Fund of China (grant no. 17VHQ012), the Fujian Provincial Natural Science Foundation of China (grant no. 2020J0141), Marine Science Base Scientific Research Training and Scientific Research Ability Enhancement Project of Xiamen University (grant no. J1210050) and Xiamen University Training Program of Innovation and Entrepreneurship for Undergraduates (grant nos. 2016X0619, 2016X0624, 2016X0629 and 103842017050).

\section{References}

Abakumov E., Lupachev A. \& Andreev M. 2017. Trace element content in soils of the King George and Elephant islands, maritime Antarctica. Chemistry and Ecology 33, 856-868, doi: 10.1080/02757540.2017.1384821.

Ahn I.-Y., Lee S.H., Kim K.T., Shim J.H. \& Kim D.-Y. 1996. Baseline heavy metal concentrations in the Antarctic clam, Laternula elliptica in Maxwell Bay, King George Island, Antarctica. Marine Pollution Bulletin 32, 592-598, doi: 10.1016/0025-326X(95)00247-K.

Amaro E., Padeiro A., Mão de Ferro A., Mota A.M., Leppe M., Verkulich S., Hughes K.A., Peter H.-U. \& Canário J. 2015. Assessing trace element contamination in Fildes Peninsula (King George Island) and Ardley Island, Antarctic. Marine Pollution Bulletin 97, 523-527, doi: 10.1016/j.marpolbul.2015.05.018.
Azhari A.E., Rhoujjati A. \& Hachimi M.L.E. 2016. Assessment of heavy metals and arsenic contamination in the sediments of the Moulouya River and the Hassan II Dam downstream of the abandoned mine Zeïda (High Moulouya, Morocco). Journal of African Earth Sciences 119, 279-288, doi: 10.1016/j.jafrearsci.2016.04.011.

Boutron C.F. \&Wolff E.W. 1989. Heavy metal and sulphur emissions to the atmosphere from human activities in Antarctica. Atmospheric Environment 23, 1669-1675, doi: 10.1016/0004-6981(89)90051-6.

Bueno C., Kandratavicius N., Venturini N., Figueira R.C.L., Pérez L., Iglesias K. \& Brugnoli E. 2018. An evaluation of trace metal concentration in terrestrial and aquatic environments near Artigas Antarctic Scientific Base (King George Island, maritime Antarctica). Water, Air, \& Soil Pollution 229, article no. 398, doi: 10.1007/s1 1270-018-4045-1.

Cai M.H., Lin J., Hong Q.Q., Wang Y. \& Cai M.G. 2011. Content and distribution of trace metals in surface sediments from the northern Bering Sea, Chukchi Sea and adjacent Arctic areas. Marine Pollution Bulletin 63, 523-527, doi: 10.1016/j.marpolbul.2011.02.007.

Celis J., Barra R., Espejo W., González-Acuña D. \& Jara S. 2015. Trace element concentrations in biotic matrices of Gentoo Penguins (Pygoscelis papua) and coastal soils from different locations of the Antarctic Peninsula. Water Air and Soil Pollution 226, article no. 2266, doi: 10.1007/ s11270-014-2266-5.

Chaparro M.A., Nuñez H., Lirio J.M., Gogorza C.S. \& Sinito A.M. 2007. Magnetic screening and heavy metal pollution studies in soils from Marambio Station, Antarctica. Antarctic Science 19, 379-393, doi: 10.1017/S0954102007000454.

Chen F., Lin J., Qian B., Wu Z., Huang P., Chen K., Li T. \& Cai M. 2018. Geochemical assessment and spatial analysis of heavy metals in the surface sediments in the eastern Beibu Gulf: a reflection on the industrial development of the South China Coast. International Journal of Environmental Research and Public Health 15, article no. 496, doi: 10.3390/ ijerph 15030496.

Chen Y., Gao J., Yuan Y., Ma J. \& Yu S. 2016. Relationship between heavy metal contents and clay mineral properties in surface sediments: implications for metal pollution assessment. Continental Shelf Research 124, 125-133, doi: 10.1016/j.csr.2016.06.002.

Chu Z., Yang Z., Wang Y., Sun L., Yang W., Yang L. \& Gao Y. 2019. Assessment of heavy metal contamination from penguins and anthropogenic activities on Fildes Peninsula and Ardley Island, Antarctic. Science of The Total Environment 646, 951-957, doi: 10.1016/j.scitotenv.2018.07.152.

Hakanson L. 1980. An ecological risk index for aquatic pollution control-a sedimentological approach. Water Research 14, 975-1001, doi: 10.1016/0043-1354(80)90143-8.

Huang T., Sun L., Wang Y., Chu Z., Qin X. \& Yang L. 2014. Transport of nutrients and contaminants from ocean to island by emperor penguins from Amanda Bay, East Antarctic. Science of The Total Environment 468-469, 578-583, doi: 10.1016/j.scitotenv.2013.08.082.

Kariminia S., Ahmad S.S., Hashim R. \& Ismail Z. 2013. Environmental consequences of Antarctic tourism from a 
global perspective. Procedia-Social and Behavioral Sciences 105, 781-791, doi: 10.1016/j.sbspro.2013.11.081.

Kaushik A., Kansal A., Santosh Meena, Kumari S. \& Kaushik C.P. 2009. Heavy metal contamination of river Yamuna, Haryana, India: assessment by metal enrichment factor of the sediments. Journal of Hazardous Materials 164, 265-270, doi: 10.1016/j.jhazmat.2008.08.031.

Li Z., Liu X. \& Shang R. 1992. The characteristics and mechanism of island-arc volcanism on the central and southern Fildes Peninsula, King George Island, Antarctica. Acta Geologica Sinica 5, 39-57, doi: 10.1111/j.1755-6724.1992. mp5001003.x.

Lu Z., Cai M., Wang J., Yang H. \& He J. 2012. Baseline values for metals in soils on Fildes Peninsula, King George Island, Antarctica: the extent of anthropogenic pollution. Environmental Monitoring and Assessment 184, 7013-7021, doi: 10.1007/s10661-011-2476-x.

Majer A.P., Petti M.A.V., Corbisier T.N., Ribeiro A.P., Theophilo C.Y.S., Ferreira P.A.D.L. \& Figueira R.C.L. 2014. Bioaccumulation of potentially toxic trace elements in benthic organisms of Admiralty Bay (King George Island, Antarctica). Marine Pollution Bulletin 79, 321-325, doi: 10.1016/j.marpolbul.2013.12.015.

Michel R.F.M., Schaefer C.E.G.R., López-Martínez J., Simas F.N.B., Haus N.W., Serrano E. \& Bockheim J.G. 2014. Soils and landforms from Fildes Peninsula and Ardley Island, maritime Antarctica. Geomorphology 225, 76-86, doi: 10.1016/j.geomorph.2014.03.041.

Müller G. 1969. Index of geoaccumulation in sediments of the Rhine River. GeoJournal 2, 108-118.

Müller G. 1979. Schwermettalle in den sedimenten des Rheins-veranderungen seit 1971. (Heavy metals in the sediments of the Rhine-changes since 1971.) Umschau 79, 778-783.

Peter H.-U., Buesser C., Mustafa O. \& Pfeiffer S. 2008. Risk assessment for the Fildes Peninsula and Ardley Island, and development of management plans for their designation as Specially Protected or Specially Managed Areas. Dessau, Germany: German Environmental Agency.

Planchon F.A.M., Boutron C.F., Barbante C., Cozzi G., Gaspari V., Wolff E.W., Ferrari C.P. \& Cescon P. 2002. Changes in heavy metals in Antarctic snow from Coats Land since the mid-19th to the late-20th century. Earth and Planetary Science Letters 200, 207-222, doi: 10.1016/ S0012-821X(02)00612-X.

Ribeiro A.P., Figueira R.C.L., Martins C.C., Silva C.R.A., França E.J., Bícego M.C., Mahiques M.M. \& Montone R.C. 2011. Arsenic and trace metal contents in sediment profiles from the Admiralty Bay, King George Island, Antarctica. Marine Pollution Bulletin 62, 192-196, doi: 10.1016/j.marpolbul.2010.10.014.

Roberts S.J., Monien P., Foster L.C., Loftfield J., Hocking E.P., Schnetger B., Pearson E.J., Juggins S., Fretwell P., Ireland L., Ochyra R., Haworth A.R., Allen C.S., Moreton S.G., Davies S.J., Brumsack H.-J., Bentley M.J. \& Hodgson D.A. 2017. Past penguin colony responses to explosive volcanism on the Antarctic Peninsula. Nature Communication 8, article no. 14914, doi: 10.1038/ncomms14914.
Santamans A.C., Boluda R., Picazo A., Gil C., Ramos-Miras J., Tejedo P., Pertierra L.R., Benayas J. \& Camacho A. 2017. Soil features in rookeries of Antarctic penguins reveal sea to land biotransport of chemical pollutants. PLoS One 12, e0181901, doi: 10.1371/journal.pone.0181901.

Santos I.R., Silva-Filho E.V., Schaefer C.E., Albuquerque-Filho M.R. \& Campos L.S. 2005. Heavy metals contamination in coastal sediments and soils near the Brazilian Antarctic Station, King George Island. Marine Pollution Bulletin 50, 185-194, doi: 10.1016/j.marpolbul.2004.10.009.

Santos I.R., Silva-Filho E.V., Schaefer C.E., Sella S.M., Silva C., Gomes V., Passos M.J. \& Van Ngan P. 2006. Baseline mercury and zinc concentrations in terrestrial and coastal organisms of Admiralty Bay, Antarctica. Environmental Pollution 140, 304-31 1, doi: 10.1016/j.envpol.2005.07.007.

Sheppard D.S., Claridge G.G.C. \& Campbell I.B. 2000. Metal contamination of soils at Scott Base, Antarctica. Applied Geochemistry 15, 513-530, doi: 10.1016/S0883-2927(99)00055-4.

Singh K.P., Malik A., Sinha S., Singh V.K. \& Murthy R.C. 2005. Estimation of source of heavy metal contamination in sediments of Gomti River (India) using principal component analysis. Water, Air, and Soil Pollution 166, 321-341, doi: 0.1007/s1 1270-005-5268-5.

Tomlinson D.L., Wilson J.G., Harris C.R. \& Jeffrey D.W. 1980. Problems in the assessment of heavy-metal levels in estuaries and the formation of a pollution index. Helgoländer Meeresuntersuchungen 33, 566-575, doi: 10.1007/BF02414780.

Trevizani T.H., Figueira R.C.L., Ribeiro A.P., Theophilo C.Y.S., Majer A.P., Petti M.A.V., Corbisier T.N. \& Montone R.C. 2016. Bioaccumulation of heavy metals in marine organisms and sediments from Admiralty Bay, King George Island, Antarctica. Marine Pollution Bulletin 106, 366-371, doi: 10.1016/j.marpolbul.2016.02.056.

Wang J., Wang Y., Wang X. \& Sun J. 2007. Penguins and vegetations on Ardley Island, Antarctica: evolution in the past 2,400 years. Polar Biology 30, 1475-1481, doi: 10.1007/ s00300-007-0308-9.

Wang X., Liu K., Zhu L., Li C., Song Z. \& Li D. 2021 . Efficient transport of atmospheric microplastics onto the continent via the East Asian summer monsoon. Journal of Hazardous Materials 414, article no. 125477, doi: 10.1016/j. jhazmat.2021.125477.

Wang Y., Yang L., Kong L., Liu E., Wang L. \& Zhu J. 2015. Spatial distribution, ecological risk assessment and source identification for heavy metals in surface sediments from Dongping Lake, Shandong, east China. Catena 125, 200-205, doi: 10.1016/j.catena.2014.10.023.

Webster J., Webster K., Nelson P. \& Waterhouse E. 2003. The behaviour of residual contaminants at a former station site, Antarctica. Environmental Pollution 123, 163-179, doi: 10.1016/S0269-7491(02)00403-7.

Wedepohl K.H. 1995. The composition of the continental crust. Geochimica et Cosmochimica Acta 59, 1217-1232, doi: 10.1016/0016-7037(95)00038-2.

Wolff E.W., Suttie E.D. \& Peel D.A. 1999. Antarctic snow record of cadmium, copper, and zinc content during the twentieth century. Atmospheric Environment 33, 1535-1541, doi: 10.1016/S1352-2310(98)00276-3. 
Yang Z., Wang Y., Shen Z., Niu J. \& Tang Z. 2009. Distribution and speciation of heavy metals in sediments from the mainstream, tributaries, and lakes of the Yangtze River catchment of Wuhan, China. Journal of Hazardous Materials 166, 1186-1194, doi: 10.1016/j. jhazmat.2008.12.034.

Yuan C.-G., Shi J.-B., He B., Liu J.-F., Liang L.-N. \& Jiang G.-B. 2004. Speciation of heavy metals in marine sediments from the East China Sea by ICP-MS with sequential extraction. Environment International 30, 769783, doi: 10.1016/j.envint.2004.01.001.

Zhang Z., Li J., Mamat Z. \& Ye Q. 2016. Sources identification and pollution evaluation of heavy metals in the surface sediments of Bortala River, northwest China. Ecotoxicology and Environmental Safety 126, 94-101, doi: 10.1016/j. ecoenv.2015.12.025. 